\title{
DATA IN THE INTERNET OF THINGS ERA: THE PROPERTIZATION OF DATA IN LIGHT OF CONTEMPORARY BUSINESS PRACTICES
}

\author{
Sidi Mohamed Sidi Ahmed* \\ International Islamic University Malaysia \\ Duryana Mohamed \\ International Islamic University Malaysia
}

\begin{abstract}
Data is at the heart of the digital age or, as some put it, "the new oil", "the next natural resource" and the "currency of the $21^{\text {st }}$ century" that everything depends on to function and operate. The Internet of Things (IoT), which aims to connect things to the Internet and interconnect them with each other, could have a huge impact on data generation and dissemination as there will be data streams from countless sources. The centrality of data and its countless value in today's world do not, however, end contention and controversial views about its nature. Every stakeholder looks at data from his own perspective. Merchants and the business community view data as a valuable asset and commodity that could generate huge profits. In the existing legal systems, courts traditionally excluded information (data) from the ambit of property and current statutes seem to be silent about the issue of dealing with data as property. This paper attempts to study the propertization of data in light of contemporary business practices and the existing laws through consulting some relevant statutory laws and court cases. The aim of the discussion is to pay attention to the gap between business practices and current legal protection available for data or information. This paper is believed to be useful and timely as data propertization is an ongoing contentious issue that surfaces with every new wave of datagenerated technology such as the IoT.
\end{abstract}

Keywords: Data propertization; Business practice; The law

Received: 11 February 2019

Accepted: 20 August 2019

\section{INTRODUCTION}

Data or information is at the heart of the technological age and the most important engine of progress on it. Therefore, there should be no surprise when some exaggeratedly describe information as the "the new oil" or "the next natural resource" (Haup, 2016) that everything depends on to function and operate. The Internet of Things (IoT), which is seen as an extension of the Internet, could have a huge impact on data generation and dissemination as there will be data streams from countless sources. The term "IoT" is given to technologies that can connect things to the Internet, interconnect them with each other and enable them to provide information about their

\footnotetext{
Corresponding Author. Department of Civil Law, AIKOL, International Islamic University Malaysia, Kuala Lumpur, Malaysia, Tel: (006)0183500342, E-mail: kaldbkar@yahoo.com
} 
locations and the things they are attached to. IoT was firstly created by a few researchers in 1999 (Ahmed \& Zulhuda, 2015) and thereafter became a common term. There was around 12.5 billion devices connected to the Internet in 2010 and the number is estimated to reach 50 billion by 2020 (Evans D. , 2011). The increase in interconnectivity will significantly benefit people, help improve the existing services and create new ones. The effect of this ever-connectivity on data is obvious. As in the IoT era, there will supposedly be a sea of data supplied with never-ending sources. For example, data volumes expand between 50 and 60 percent every year (Greengard, 2015). The centrality of data and its countless value in today's world, do not, however, end contention and controversial views about its nature. Accordingly, every stakeholder looks at data from his own perspective: for some there is no need for new protection of data, but for others, data is the currency of time and a profitable field for investments. Therefore, merchants and the business community in general seem to deal with data as a valuable asset and commodity that could generate huge profits and thus investments in technology that increases data-nest. The importance of data and its financial value are not overlooked by the academic society, but the way of dealing with it as property or something else remains unsettled. The existing laws in most countries provide some form of protection to selected types of information under certain conditions on a non-proprietary basis. For example, judges traditionally excluded information (data) from the ambit of property and current statutes seem to be silent on the propertization of data. It is true that intellectual property (IP) and data protection laws, among others, provide some form of protection to data or information, but such protection seems to be insufficient for the currency of the digital age (data). For example, copyright and patent laws protect some mind creations (information embedded in physical forms) under certain conditions, such as originality, and material forms for copyrightable works (Copyright Act, 1987). For patent, the protected work has to be described as a new invention that is industrially applicable (Patents Act, 1983). The issue here is that various types of data or information may not qualify for protection under IP laws and also under data protection laws, which is concerned with how personal data is processed in the digital environment. For reasons such as these, some rightly argue for the propertization of data as it could help cover most of the unprotected data or information under existing laws.

This paper argues the availability and value of data, among others, in order to necessitate approaching data from untraditional aspects and dealing with it as a valuable self-existent thing rather than consider it merely as a carrier of ideas. In this regard, the propertization of data could arguably be one of the available legal means for safeguarding interests in data or information in the digital age. Dealing with data and information under the umbrella of property could kill two birds with one stone. On one hand, the concept of property is a known concept in the legal field and has a wide flexible meaning that can cover different things such as tangible and intangible things. On the other hand, the law uses the term "property" when dealing with information or data. For example, the law uses "intellectual property" to refer to various rights granted to those who have rights under the IP laws. To illustrate this approach, this paper attempts to study the propertization of data in light of contemporary business practices and some available court cases. This study attempts to pay attention to the gap between business practices that seem to consider data as property and the current legal protection available to data or information that may not cover some valuable data.

The second section of this paper provides definitions of the main terms and concepts used in this paper such as the IoT, data, information, property and bundle of right. The scope and limitations 
of concepts and terms used in this study is also mentioned here. In the third section, data propertization from a business perspective is discussed in light of contemporary practices of the business community. The fourth section deals with data propertization from a legal point of view. This section examines selected relevant cases and statutory laws in order to know how the existing laws address the issue of data propertization. In other words, the discussion seeks to answer questions regarding the extent of the existing laws' opposition to data propertization and the future possibility of classifying data or information as property. Lastly, the fifth and final section provides concluding points that summarize the outcome of the discussion as well as suggestions or recommendations to further the ongoing discussion about data propertization in the digital age. It is believed that this study will be useful and timely as data propertization is an ongoing contentious issue that surfaces with every new wave of data-generated technology such as the IoT. This paper is a doctrinal study, relaying on both legal and non-legal sources to collect and analyse the subject matter. With regard to the objective, this study does not restrict itself to specific regions, jurisdictions or legal systems. Instead, it involves a cross-jurisdictional examination. Nonetheless, examples of current available protection for types of data or information may be taken from Malaysian laws, especially (Personal Data Protection Act , 2010) and intellectual property laws.

\section{DEFINITIONS}

Firstly, it is essential to commence with the brief definitions of terms used in this topic. Even though these terms is known to those who are familiar with the topic and may also be understood by the layman, their definitions are important as this paper will discuss a composite term, namely "propertization of data." Therefore, it is vital to define the individual words "property" and "data" in order to understand their composition "propertization of data". The term "IoT", which encompasses the words "Internet", "of" and "things", might be the proper term to start with. The Internet is defined as "a computer system that allows people in different parts of the world to exchange information” (MACMILLAN English Dictionary for Advanced Learners, 2007). In the linguistic sense, the term "thing" has various meanings, one of which is "an object, or an item" that is "used when you cannot or do not want to refer to the object or item in a more specific way" (MACMILLAN English Dictionary for Advanced Learners, 2007). In the context of the IoT, things can virtually include anything such as computers, electronic devices, food package, clothing, people, animals, trees, house (Madakam, Ramaswamy, \& Tripathi, 2015), cars and so forth. Unlike its individual words, the IoT is not easy to define. Accordingly, some authors who analysed various IoT existing definitions rightly concluded that "a comprehensive definition of the Internet of Things is not easy" (Minerva, Biru, \& Rotondi, 2015). This could be due to the different aspects and approaches taken by various stakeholders. However, it does not mean that there are no efforts to define the phenomenon. In fact, there are various definitions and this paper will quote some of them in order to approximate the meaning of IoT to the readers. IoT can be defined as "an emerging global Internet-based information architecture facilitating the exchange of goods and services" (Weber \& Weber, 2010, p. 1). It is also defined as "networks of objects that communicate with other objects and with computers through the Internet" (Fischer, 2015, p. 1). In more details, IoT "refers to the general idea of things, especially everyday objects, that are readable, recognizable, locatable, addressable through information sensing device and/ or controllable via the Internet, irrespective of the communication means" (Patel \& Patel, 2016). All the above definitions provide that the idea that IoT revolves around connecting things, including everyday objects, to the Internet in ways that enable them to process data and facilitate the exchange of services and goods. 
Needless to say, the term "IoT" was firstly coined in 1999 with the vision that computers would be able to collect data and render it into useful information without human intervention (IbarraEsquer, González-Navarro, Flores-Rios, Burtseva, \& Astorga-Vargas, 2017). It is also noteworthy that the IoT is not the sole name used to describe this technology. Its other names include Internet of People (IoP), Internet of Anything (IoA), Internet of Everything (IoE) and Internet of Data (IoD) (Oriwoh \& Conrad, 2015). The main purpose of the IoT is to connect unconnected things in all places and at all times in order to create smart environments where cities, transport, energy and other areas can become more intelligent (Patel \& Patel, 2016) and (River Publishers Series in Communication, 2014). The IoT groups technologies into three categories: the first one enables thing to acquire contextual information; the second enables things to process such contextual information; and the third helps improve privacy and security (River Publishers Series in Communication, 2014). The above categories have been divided into functional and nonfunctional categories but the details of these groups and their functionality are beyond the scope of this paper, which concentrates only on data and the IoT impact therein. As mentioned above, the impact of the IoT on data is likely to be huge as there will be an outpouring of data streaming from almost everything. Therefore, the issue of data propertization might impose itself on every stakeholder. It necessitates knowing the meaning of data and property and their combination "propertization of data."

Semantically, data is "facts and statistic used for reference of analysis" (Soanes \& Stevenson, n.d.). The term "data" is usually used with other words such as "personal data", "big data", "sensitive data" etc., so its definition depends on the context. For example, in data protection laws, personal data includes any information relating to an identified or identifiable natural person... who could be identified directly or indirectly from such information etc. (Personal Data Protection Act, 2010). The identified information can be names, addresses or other relevant information. "Information" is another word used here and its meaning is almost similar to data. For example, in business usage, information is "facts or details about a person, company or product, etc." (Top, 2015) and in the linguistic sense, it is "knowledge or facts about someone or something" (MACMILLAN English Dictionary for Advanced Learners, 2007). In practice, there is a difference between data and information. Before arrangement or being in a useful form, it is called data and after it is organized and ready for use, it becomes information (Top, 2015). In this paper, the terms "data" and "information" are interchangeable. In another expression, the term "data" used in this paper includes information without distinction between personal or non-personal information. Therefore, the call for data propertization includes propertization of personal and non-personal data and also data and information.

Like the IoT, the term "property" is not easy to concretely define (Niazi, 2015, p. 6) as its notion is viewed differently by the layman and experts. In the layman perspective, property can be in a tangible thing, such as cars, or intangible thing, such as the goodwill of a business. However, for lawyers, property is a right rather than an object (Hammond, 1990-1992). In the legal sense, property can be defined as "anything that can be owned" and this includes real, personal, tangible and intangible property (Martin, 2003). In the middle of the $18^{\text {th }}$ century, property was described by Blackstone as "that sole despotic dominion which one man claims and exercises over the external things of the world, in total exclusion of the right of any other individual in the universe" (McCary, 2001, p. 3) According to this description, property is seen as an absolute dominion over things (Baron, 2014) or, in other words, it is a relationship between a person and things. However, 
the most chosen definition among academics today is the so-called "bundle of rights" concept that "denies any fixed meaning to property and deemphasizes the importance of the thing with regard to which the rights are claimed" (Bell \& Parchomovsky, 2005). Historical speaking, the "bundle of rights" metaphor can be traced back to Wesley Newcomb Hohfeld, whose "unpacking of legal rights into component jural correlatives and opposites provided both the "intellectual justification" and the "analytic vocabulary" for the bundle-of-rights conception" (Baron, 2014, p. 62) Hohfeld's work led to "the development of the notions that property consists" of no things other than the legal relationships among people (Baron, 2014). In this regard, property is seen as relationship among people and not their relationship with things. In "the bundle of rights conception", the aggregation of rights, privileges, powers and duties constitute property (the right to use, manage, the right to the income, the right to secure) (Bell \& Parchomovsky, 2005).

Considering property as a right rather than absolute dominion could be useful in dealing with data because data cannot be controlled. Unlike tangible things, data can be used by more than one person at the same time. Therefore, the term "information property" is used "to describe certain private rights in information that connote some degree of control over relevant information"; it is not property in terms of tangible things such as land because information is different from tangible items (Lipton, 2004). In this paper, the term "data propertization" means dealing with data as a valuable thing that needs to be protected; here, "data" includes all types of data regardless of the origin or confidentiality. In other words, data includes personal data as defined in data protection laws, commercial data and other types of data . Calling for the propertization of data in this paper is calling for granting more rights to the right-holders of data and data subjects and enabling them to have more control over it. The scope and nature of the said proprietary rights should be specified by laws and regulations. Data property regime could enable data right-holders and data subjects to seek compensation in case of misuse of data and other similar situations.

Regarding challenges imposed by the IoT on the existing legal systems, including property law, it is said that the IoT "will be a legal tsunami, the intensity and magnitude of which are unknown to date" (Barbry, 2012) There will be huge amounts of raw data that needs a lot of resources and effort in order to be rendered as information for use. This will, in return, necessitate viewing data as an asset or valuable thing rather than a carrier of ideas or a medium. The following section will examine data from a commercial perspective by analysing the way it is utilized by the business community.

\section{DATA AND BUSINESS PRACTICE}

According to the Economist Intelligent Unit (EIU), "businesses can now profit from the information they possess in ways unimaginable just a decade ago". Therefore, huge amounts of data is being collected and stored by organizations who want to profit from such collected data and use it for decision making, making the existing services and goods more profitable and even creating new types of business (The Economist Intelligent Unit (EIU), 2015). This shows the importance of data for the business community as it is used as a means of making profit, which is the objective of commercial activities and a motivator for engaging in such activities. Economically speaking, information is being considered as an economic resource and an important asset of a firm that can be utilized in various ways such as delivering services, making decisions, improving performance and also selling it as a marketable product (Moody \& Walsh, 1999). The 
importance of data in the commercial world can be seen when comparing technological-based business with traditional businesses or businesses that depends on non-technological tools. In this regard, it is observed that businesses that depend on data grow faster than the physical or traditional businesses. In the United States, statistics showed that "productivity growth in the digital sector averaged 2.7 percent between 2000 and 2015, compared to 0.8 present in the physical sector". The digital sector also employed more workers than its non-digital counterpart (Mandel, 2017). Moreover, "between 2008 and 2012, world-wide cross-border trade in data increased by 49\% while trade in goods or services rose by just 2.4\%" (European Political Strategy Centre, 2017). In addition to that, information can be considered as an asset because the attribution of asset can be found in it. For example, the asset of an organization: (1) has future economic benefits; (2) is controlled by the organization; and (3) is the result of past transactions (Mandel, 2017). All these characteristics can be found in information or data as it can be used for delivering services and making decisions; an organization controls its information, which is collected as a result of prior transactions or plans.

The above indicates that data or information is being considered as property or an asset that can be invested, sold and bought like any other goods or services. Interestingly, research revealed that there are companies that are specialized in promoting, selling and buying personal data, offering platforms for such activities and mediating between personal data sellers and potential buyers. Such companies offer these services under appealing advertising slogans such as "Your data as your assets" or "Reclaim your personal data" and collect data such as financial information, social media accounts, buying pattern communication habits, visited websites, etc. (Abraham \& Oneto, 2015). One recent example of using data as a commodity or good is the Cambridge Analytica data scandal where the personal data of more than 50 million Facebook users were used by the said company to manipulate the outcome of the 2016 presidential election in the United States (Rosenberg, Confessore, Cadwalladr, 2018). The said scandal began when researchers persuaded around 270,000 people to download a Facebook app called "this is your digital life", which allowed the researchers to access information from the app users and their friends' Facebook profiles for a payment of USD1 or USD2 (Intouch Solutions, 2018). In this example, the personal data of the said Facebook users were sold and bought as ordinary property. Additionally, the method in which tech-companies such as Google and Yahoo collect and use personal data indicate that they consider this collected data as property. For example, Google Privacy Policy states that it collects and stores users' personal information such as names, telephone numbers, email addresses, credit cards, online activities etc., to provide and maintain its services or even to develop new ones. The above collection and usage are also done by other tech-companies such as Yahoo, Facebook and so forth. Thus, it can be said that the business community considers data as property as they invest in its technology and use it in various manners.

Contemporary business practices and the function that data plays in the digital age necessitate dealing with data as a valuable thing. Thus, the issue of data propertization has become an academic debate. Dealing with data as a good or asset has baffled the academic society because data is not traditionally considered as property even though the law offers some form of protection to certain types of information. Accordingly, there are contentious arguments among researchers on data propertization. While some understand the need for protecting data and the importance of data-free movement as a mechanism of development, others argue that there is no need for the propertization of data as the existing legal frameworks are capable of providing the required protection (Evans B. 
J., 2011). The academic opinions about data propertization will be discussed in detail in the following section, which focuses on data propertization from the legal perspective through the examination of some existing laws dealing with especial types of data and information and also selected previous cases in which the courts mentioned the propertization of data.

\section{DATA PROPERTY IN THE LEGAL PERSPECTIVE}

Generally speaking, information is regulated by various laws such as intellectual property laws, data protection laws, official secret laws, privacy laws, confidential information laws and computer crimes laws. All these laws deal with data in one way or another. For example, confidential information, which "refers to information that is confidential in nature", protects various types of information besides personal information such as government secrets, trade or business secrets as well as artistic and literary information (Jalil, 2003). Likewise, the Malaysian Official Secrets law protects official secrets, forbids the disclosure or communication of official documents and information that are classified as top secret, secret, confidential or restricted (Official Secrets Act, 1972). Additionally, computer laws prohibit the unauthorized access or modification of data stored in computers, etc. Sec. (Computer Crimes Act , 1997 ). However, it can fairly be said that these laws are protecting data on a non-proprietary basis; the information or data is mainly protected to maintain some advantages that may be lost if such information is not protected or to prevent damages that could be caused by disclosing such information. Therefore, the issue of ownership of such information or data seems to be overlooked by such laws because the courts, as some observed, "have not clearly identified confidential information as property (San, 2013, p. 676). Not only that, but in some cases, information has been clearly excluded from the scope of property, as will be cited in a later paragraph. Nonetheless, not all existing laws overlook or omit the issue of data property. For example, five states in the United States have "recognize[d] genetic information as the property of the individual from whom that information derives" (Ram, 2009, p. 141) The state of Alaska has a legislation that reads: "a DNA sample and the results of a DNA analysis performed on the sample are the exclusive property of the person sampled or analysed" (Alaska Legal Resource Center, 2015).

To fully comprehend the legal perspective of data propertization, this study will discuss the matter in light of intellectual property and data protection laws that are assumed to be the most relevant laws to this issue because on one hand, they are regulating personal and non-personal data and, on the other, they grant an assortment of rights to data right-holders (those who have rights under IP law) and data subjects. Moreover, this study will also discuss selected courts cases related to information property in order to know how law interpreters (the judiciary) look at this issue. The discussion will conclude with some academic opinions on the issue of dealing with data as property.

Intellectual property law "refers to creations of the mind: inventions; literary and artistic works; and symbols, names and images used in commerce" (World Intellectual Property Organization (WIPO), n.d) and it includes copyrights, patents, trade secrets and other laws. There are international conventions regulating intellectual property worldwide in addition to national laws. In general, the IP law aims to encourage inventions and creations by giving creators specific rights regarding their creative ideas that could benefit the society and help develop it. The details of these conventions and laws are beyond the scope of this paper, but some examples of these rights given 
by IP laws will be discussed here. For example, copyright law gives the authors of literary, musical or artistic works some rights over their creations. This includes, inter alia, the right of reproducing their works in any form, presenting performances to the public, selling or transferring their works, etc., (Copyright Act, 1987) (. These rights are granted to the holders for a specific period of time, ranging from their lifetime to 50 years after their death, for example (Copyright Act, 1987). When it comes to ownership, however, the copyright holders are granted the "ownership of copyright" (Copyright Act, 1987) and not the information or data itself. In the absence of any discussion about data or information itself, it could be assumed that the outcome of mind creations is not property in the view of intellectual property law or they are property but in the public domain. In fact, the justification or rationale of intellectual property law, which considers this law as a means of enabling public access to the intellectual outcomes and promoting creativity and dissemination of its results that could contribute to the development of the society (WIPO, 2004), indicates that intellectual property considers information as public property. In accordance with the modern view that property is a "bundle of rights", some mentioned that "intellectual property rights are proprietary in nature" (San, 2013, p. 4) Others went further and argued for the possibility of data propertization based on intellectual property as a means to protect genetic information (Ram, 2009). From the above, it can be said that intellectual property law grants some rights to mind creations provided that such creations meet specific requirements and appear in specific forms. Although such rights are proprietary in nature and can be used as a model for data property purposes, according to some, the core issue of data property seems to be ignored by intellectual property law. It leads to the discussion of data property in light of data protection law.

Historically speaking, personal data protection laws were created as a reaction to the growth of using technology to process (i.e. collect, store, transmit) information and data about individuals and things. Thus, data protection recommendations and laws first appeared in documents and enactments issued by the (United Nations-Economic and Social Council, 1992), the (European Union (EU), 1995), (Organisation for Economic Co-Operation And Development (OECD), 2013) and later became enshrined in national laws. These laws balanced between the rights of individuals to protect their privacy and interests and to encourage the movement of data as a means of economic and societal development. To achieve these objectives, data protection laws set rules and regulations (data protection principles) to be observed during the collection, storage, usage or processing of data, including the rights and responsibilities of the parties involved. Without delving into details of these rules and principles, this paper will concentrate on whether these laws consider personal data as property. In fact, data protection laws grant data subjects different rights regarding their data. Examples include: (1) the General Principle stipulating, inter alia, that personal data shall not be processed unless the data user gives his consent; (2) the Notice and Choice Principle, which obliges informing the data subject through written notice about the beginning of the processing of the personal data and its description, among others; (3) the Disclosure Principle; (4) the Security Principle; (5) the Retention Principle, (6) the Data Integrity Principle; and (7) the Access Principle (Personal Data Protection Act , 2010). These principles give data subjects various rights and impose penalties on those who contravene the law with fines (up to MYR30000 in Malaysia) or imprisonment (up to 2 years) or both (Personal Data Protection Act , 2010). Just as intellectual property, however, data protection law seems to overlook the issue of data property. Both intellectual property and data protection laws give rights to data rightholders and data subjects. The former includes rights that can be used to generate financial benefits while the latter focuses on non-financial benefits such preventing privacy invasion. The above 
differences could be attributed to the nature of information or data protected; for intellectual property, it is the data that is created by the authors whereas for data protection law, it is about the individuals' personality and related matters. As IP laws do, data protection laws give rights to data subjects and set rules to be followed in processing data, but the law does not provide much help to determine whether data can be considered as property. The following paragraph will discuss data propertization from the judges' point of views.

Generally speaking, judges are reluctant to clearly describe data as property (San, 2013) and, in some occasions, they clearly mentioned that information is not property. For example, in the case of (Oxford v Moss, 1979) which involved taking confidential information in an examination paper, the High Court was asked, among other things, to decide whether confidential information is considered intangible property under the Theft Act 1968. The Court held that the said confidential information is not intangible property and therefore it cannot be stolen. Even though this case was a criminal case, the Court clearly stated that confidential information is not property. In a similar Canadian case, (R. v. Stewart, 1988), in which the defendant tried to obtain confidential information through someone who has no authority to access such information, the Court was asked to decide about the propertization of information in the context of criminal law. In response to this, the Court held that confidential information is not property under the theft law. The rejection of the propertization of information in criminal cases has also been accepted by judges in non-criminal matters. For example, in (Phipps v Boardman , 1966), one of the judges, Lord Upjohn, was deciding whether "knowledge of the company's affairs" can be considered as part of its trust assets. He rejected the idea of information as property, saying that it "is not property in any normal sense" because "it is normally open to all who have eyes to read and ears to hear." Delving into the rationale behind the cases is beyond the scope of this paper because the abovementioned cases are examples of the judicial opinion about data propertization. From the above, it seems that Courts are unwilling to give the attribution of property to confidential information. On the contrary, the judges sometimes repudiate this attitude clearly. For example, in the course of delivering the judgment in (R. v. Stewart, 1988), it was clearly mentioned that if confidential information is to be protected by the criminal law as property, such protection should be done by a legislative enactment and not by extending the concept of property by the judicial (Hammond, 1990-1992).

As a conclusion to the discussion, it can be fairly stated that the existing legal frameworks protecting data or information, especially data protection and intellectual property laws, do not provide a clear answer as to whether data is property. From their perspective, the judges are reluctant or unwilling to take responsibility in extending the concept of property to data or information. Without doubt, the existing laws provide protection only to special data or information in special circumstances. However, the ability of these legal rules to effectively deal with the challenges imposed by new technology can be questioned. As an illustration, the IP law protects information that has especial attributions such originality and material forms that can be copyrightable works (Copyright Act, 1987) or industrial applicability as in patentable information (Patents Act, 1983). These strict conditions may not be found in some valuable data. The same can be said about data protected by virtue of data protection law. For example, the Malaysian (Personal Data Protection Act , 2010) only applies to processing "personal data in respect of commercial transactions". Surely, there is a considerable amount of personal data processed outside the scope of commercial transaction that will not be protected by this important law in the country. The propertization of data could arguably help protect important valuable data and 
information that are not protected by the existing laws. This paper is supporting those who are calling for the necessity of approaching information and data in general from new aspects and providing suitable legal protection to all valuable data regardless of its origin or nature. Data property supporters believe that the propertization of data will provide many benefits and help protect interests related to data, which is considered as the currency of the digital age. For example, the propertization of personal data could enable individuals to sell their data and receive compensation for its use. Moreover, the cost associated with collecting and processing personal data could enforce companies to protect such data (Samuelson, 2000). The propertization of personal data is likely to lead firms to minimize collecting and processing personal data, which in turn may achieve privacy goals and, at the same time, allow those who wish to sell their personal data to benefit from the market (Samuelson, 2000). Based on the above discussion, the property right approach is seen as a means of protecting personal data and, at the same time, providing opportunities for individuals to financially benefit from their data, which will eventually flourish the market by providing accurate and useful personal information. The opponents of data propertization, however, disagree and argue that the propertization of data will not provide better protection than what is already offered by relevant existing statutory regulating personal data. For example, while rejecting the claim that the ownership of patients' data by the patients will enhance privacy and make data available for research purposes, Barbara J. Evans asserted that "property rights may not be the right locus for reform" because under property regime, personal data could still be used without the consent of data subjects etc., (Evans B. J., 2011, p. 75). Although the above discussion is within the context of personal data, it can be said that the propertization of personal data includes a call for the propertization of all types of data. The reason is that while non-personal data is usually protected for financial interests, personal data is usually protected for non-financial reasons such as privacy and dignity of human being. Moreover, some existing laws such the IP law allow people to financially benefit from non-personal information such as information regulated by copyright and patents laws. The authors of this paper are inclined to the view that, while it could be true that the propertization of data may not provide better privacy protection than the existing laws as previously claimed, data propertization could benefit data right-holders and data subjects by strengthening their stand in other aspects and enabling them to dictate about how the data should be dealt with. It can also be noted that the argument of data-property opponents seems to be based on the traditional and common sense view that property is "a relation between a person and a thing" (McCary, 2001, p. 2). However, such an argument could be overturned if property is understood or defined as an assortment or a bundle of rights as agreed by most modern academics (Bell \& Parchomovsky, 2005). As an illustration, existing laws grant various rights in terms of personal and non-personal data, as applied in the IP and data protection laws. Therefore, if data property is seen as granting more rights to data subjects and data right-holders, the argument of data property opponents could become baseless because it opposes the existing legal systems that recognize various rights in information.

\section{CONCLUSION AND RECOMMENDATIONS}

\subsection{Conclusion}

As discussed and illustrated above, the propertization of data (including information in the usage of those who differentiate between data and information) is an argumentative debate. On one hand, 
the nature of data as an intangible thing that can simultaneously be used by many users at the same time deems the calling for the propertization of such data as unreasonable and not easy to be comprehended at least by those who define property as the "sole despotic dominion" over things. On the other hand, the importance of data as a mechanism and engine of the digital age necessitates approaching it from a new angle and dealing with it as a valuable thing. Current business practices seem to consider data as a valuable asset. Statistics show that technological-based businesses grow faster than its counterpart and the amount of money invested in digital businesses is huge. Additionally, buying and selling data is also another manifestation of dealing with data as property in the business sector. In the legal perspective, the existing legal systems related to information or data seem to protect data on non-proprietary matters. Some available court decisions clearly excluded information from being described as property. Statutory laws provide protection to some types of data in specific contexts such data in IP and personal data uses. Due to their applicability to specific data under specific conditions, the existing laws seem to be unable to encompass evolving technology and therefore, various types of valuable data could legally be unprotected. Some academics call for "data property regime" as a means of strengthening the available data protection rules and protecting unprotected data.

\subsection{Recommendations}

This paper argues that the availability, value and potentiality of data and information in the digital age and the insufficiency of current legal laws should be taken as an inducement to approach data from different angles in order to provide adequate protection to different types of data. This can arguably be done through extending the scope of legal provisions regulating data and information, especially those found in intellectual property and data protection laws, to cover some types of unprotected data or through especial enactments. The propertization of data could be one of the most suitable means to be adopted here. On one hand, property is a known legal concept in the field of legal studies and, on the other one, the term itself (intellectual property) is used by the law to refer to rights granted to mind creators such the owners of copyright and patents. Data property or "data property regime" is a term used to refer to the call for granting more rights and power to data right-holders and data subjects in controlling the usage of their data and information. The authors of this paper argue that intellectual property law can be used as a legal model to develop a protective mechanism based on proprietary rights to protect non-personal data and information that have values and are not protected by the current laws. The scope of proprietary rights and the types of data that it includes could be drawn by legislative bodies.

Additionally, rights granted by data protection law could also be used as a legal model to grant proprietary rights on personal data. Currently, data protection laws give data subjects the right to prevent processing, which is likely to cause damage or distress and processing for direct marketing (Personal Data Protection Act , 2010). However, in the case of contravening these by data users, data subjects may not have grounds to receive financial benefits. In the proposed data regime, data subjects should have the right to be compensated on the basis that their property (data) is unlawfully used without their consent. Data property could arguably strengthen the privacy and security of personal data as the fear of costs could lead data users to comprehensively comply with the rules and regulations of processing personal data in the digital environment. The scope and limitations of data property regime should be drawn by legislative bodies. Therefore, this paper does not concern itself with details of data property regime because its main objective is to highlight the gap between the current business practices, which deal with data as a valuable asset, 
and the legal systems that provide protection to various types of information upon existence of certain conditions.

The opponents of data propertization could argue that there is no need for the propertization of data because, instead of improving data security, such an approach will restrict data movement, which in turn may affect the society as a whole as well as the function of public bodies in accessing such data for public interests. Moreover, data propertization may also affect privacy as it will encourage dealing with privacy information as a worthless thing or a cheap asset or good that can be sold and bought and not as a sacred thing that must be respected by everyone. All these and other apprehensions highlighted by the opponents of data property are worthy notes and should be considered in the movement or direction to grant proprietary right on data. It is important to note that the types of data to be considered as property and the nature and scope of any data property regime should consider the nature of data or information, the interests of society, national security, the privacy and dignity of individuals and, at the same time, their freedom. Regarding the propertization of personal data, the issue of privacy and security should be given special attention as such data is related to human honour and dignity and therefore any proprietary right for such data should be a means to strengthen the privacy and security of such personal data.

\section{REFERENCES}

Abraham, T., \& Marguerite. (2015, May 6). Consumers as data brokers: Should they sell their personal data? Berkeley. Retrieved from https://www.ischool.berkeley.edu/sites/default/files/projects/abraham-oneto-finalpaper.pdf

Ahmed, S. M., \& Zulhuda, S. (2015). The concept of internet of things and its challenges to privacy. South East Asia Journal of Contemporary Business, Economics and Law, 8(4), $1-6$.

Alaska Legal Resource Center. (2015). Alaska statutes: Health, safety and housing. Retrieved from http://www.touchngo.com/lglcntr/akstats/statutes/title18/chapter13/section010.htm

Barbry, E. (2012). The internet of things, legal aspects what will change (everything). Communications and Stratigies 1(87), 83-100.

Baron, J. B. (2014). Rescuing the bundle-of-rights metaphor in property law. University of Cincinnati Law Review, 82(1), 57-101.

Bell, A., \& Parchomovsky, G. (2005). A theory of property. Cornell Law Review, 90(3), 531-616..

Computer Crimes Act 1997. (2011, December 1). Retrieved from https://www.nacsa.gov.my/legal.php

Copyright Act 1987. (2012, July 1). Retrieved from http://www.myipo.gov.my/wpcontent/uploads/2016/12/Copyright-Act-1987-Act-332.pdf

European Political Strategy Centre. (2017, January 11). Enter the data economy. European Commision. Retrieved from https://ec.europa.eu/epsc/sites/epsc/files/strategic_note_issue_21.pdf

Evans, B. J. (2011). Much ado about data ownership. Harvard Journal of Law and Technology, 25(1), 69-130. 
Evans, D. (2011). The internet of things - How the next evolution of the internet is changing everything. Cisco Internet Business Solutions Group. Retrieved from https://www.cisco.com/c/dam/en_us/about/ac79/docs/innov/IoT_IBSG_0411FINAL.pdf

Fischer, E. A. (2015, October 13). The internet of things: frequently asked questions. Congressional Research Service. Retrieved from https://fas.org/sgp/crs/misc/R44227.pdf

Greengard, S. (2015). The internet of things. Massachusetts Institute of Technology.

Hammond, R. (1992). Personal property commentary and materials. Oxford University Press.

Haup, M. (2016, May 2). Data is the new oil-A ludicrous proposition. Medium. Retrieved from https://medium.com/project-2030/data-is-the-new-oil-a-ludicrous-proposition1d91bba4f294

Ibarra-Esquer, J. E., González-Navarro, F. F., Flores-Rios, B. L., Burtseva, L., \& Astorga-Vargas, M. A. (2017). Tracking the evolution of the internet of things concept across different application domains. Sensors, 17(6) 1379.

Intouch Solutions. (2018). Cambridge analytica scandal: Don't blame facebook. blame bad ethics. Retrieved from https://www.intouchsol.com/wpcontent/uploads/ CambridgeAnalyticaPOV_IntouchSolutions.pdf

Jalil, J. A. (2003). Confidential information law in Malaysia. Petaling Jaya: Sweet \& Maxwell Asia.

Lipton, J. (2004). Information property: rights and responsibilities. Florida Law Review, 56(1),135-194.

MACMILLAN English Dictionary for Advanced Learners. (2007). Macmillan Publishers Limited. Madakam, S., Ramaswamy, R., \& Tripathi, S. (2015). Internet of things (IoT): A literature review. Journal of Computer and Communications, 3(5),164-173.

Mandel, M. (2017, July 12). The economic of data: Why data is not like oil. Progressive Policy Institute. Retrieved from http://www.progressivepolicy.org/wpcontent/uploads/2017/07/ Power-of-Data-One-Pager

Martin, E. A. (Ed.). (2003). The oxford dictionary of law (5 ed.). Oxford University Press.

McCary, L. T. (2001). Ownership: A Case Study in the Representation of Legal Concepts. The Author.

Minerva, R., Biru, A., \& Rotondi, D. (2015). Towards a definition of the internet of things (IoT). IEEE Internet Initiative, 1, 1-86.

Moody, D., \& Walsh, P. (1999). Measuring the value of information: An asset valuation approach. Semantic Scholar. Retrieved from https://www.semanticscholar.org/paper/Measuringthe-Value-Of-Information-An-Asset-Moody-Walsh/ bc8ee8f7e8509db17e85f8108d41ef3bed5f13cc

Niazi, S. M. (2015). The law of property. International Journal of Liberal Arts and Social Science, $3(6), 7-12$.

Official Secrets Act 1972. (2016, January 1). Retrieved from http://www.agc.gov.my/agcportal/ uploads/files/Publications/LOM/EN/Act\%2088.pdf

Organisation for Economic Co-Operation And Development (OECD). (2013). Privacy framework: OECD guidelines governing the protection of privacy and transborder flows of personal data. Retrieved from https://www.oecd.org/internet/ieconomy/ oecdguidelinesontheprotectionofprivacyandtransborderflowsofpersonaldata.htm

Oriwoh, E., \& Conrad, M. (2015). Things in the internet of things: Towards a definition. International Journal of Internet of Things, 4(1), 1-5.

Oxford v Moss (1979) 68 Cr App Rep 183. Retrieved from http://www.elawresources.co.uk/Oxford-v-Moss.php 
Parliament, E. (1995). Directive 95/46/EC of the European Parliament and of the Council of 24 October 1995 on the protection of individuals with regard to the processing of personal data and on the free movement of such data. Official Journal of the European Communities, number L, 281, 31-50.

Patel, K. K., \& Patel, S. M. (2016). Internet of things-IoT: Definition, characteristics, architecture, enabling technologies, application \& future challenges. International Journal of Engineering Science and Computing (IJESC), 51(5), 6122.

Patents Act 1983. (2016, August 16). Retrieved from http://www.myipo.gov.my/wpcontent/uploads/2016/09/PATENT-ACT-1983-ACT-291.pdf

Personal Data Protection Act 2010. (2016, June 15). Retrieved from https://www.nacsa.gov.my/legal.php

Phipps v Boardman (1966) 3 All ER 721. Retrieved from https://swarb.co.uk/phipps-v-boardmanhl-1966-2/

Ram, N. (2009). Assigning rights and protecting interests: Constructing ethical and efficient legal rights in human tissue research. Harvard Journal of Law \& Technology, 23(1),141-177.

River Publishers Series in Communication. (2014). Internet of things- From research and innovation to market deployment (O. V. Friess, Ed.) Aalborg, Denmark: River Publishers.

Samuelson, P. (2000). Privacy as intellectual property? Stanford Lawreview, 52(5), 1125-1173.

San, T. P. (2013). Intellectual property law in Malaysia. Petaling Jaya: Sweet \& Maxwell Asia.

Soanes, C., \& Stevenson, A. (Eds.). (n.d.). The concise oxford english dictionary (11 ed.). Oxford University Press.

R. v. Stewart, [1988] 1 S.C.R. 963. Retrieved from https://scc-csc.lexum.com/scc-csc/scccsc/en/331/1/document.do

The Economist Intelligent Unit (EIU). (2015). The business of data. Retrived from https://eiuperspectives.economist.com/sites/default/files/images/Business\%20of\%20Dat a\%20briefing\%20paper\%20WEB.pdf

Rosenberg, M., Confessore, N., Cadwalladr, C. (2018). The New York Times. (2017, March 17). How Trump consultants exploited the Facebook data of millions. The New York Times Retrieved from https://www.nytimes.com/2018/03/17/us/politics/cambridge-analyticatrump-campaign.html

Abraham, T., \& Oneto, M. (2015). Consumers as data brokers: Should they sell their personal data? . Retrieved from

https://www.ischool.berkeley.edu/sites/default/files/projects/abraham-oneto-finalpaper.pdf

Top, J. (2015, August 2). Information value in a decision making context. Radboud University Nijmegen. Retrieved from https://pdfs.semanticscholar.org/f5f1/ 2d846724d701b74976f6a1e74de619533fdb.pdf

United Nations-Economic and Social Council. (1992, February 20). Revised version of the guidelines for the regulation of computerized personal data files"-(E/CN.4/1990/72.) Retrieved from https://digitallibrary.un.org/record/85149?ln=en\#record-files-collapseheader

Weber, R. H., \& Weber, R. (2010). Internet of tings legal perspectives. Berlin: Springer.

WIPO. (2004). Intellectual Property Handbook. Geneva: WIPO Publication No. 489 (E) .

World Intellectual Property Organization (WIPO). (n.d). What is Intellectual Property? Switzerland, Geneva: WIPO Publication No. 450(E) . 